J Am Chem Soc. 2007 March 07; 129(9): 2456-2457. doi:10.1021/ja0693587.

\title{
Reactivation of the p53 Tumor Suppressor Pathway by a Stapled p53 Peptide
}

\author{
Federico Bernal, Andrew F. Tyler, Stanley J. Korsmeyer, Loren D. Walensky, and Gregory L. \\ Verdine \\ Department of Chemistry and Chemical Biology, Harvard University, Cambridge, Massachusetts \\ 02138, Program in Cancer Chemical Biology, Dana-Farber Cancer Institute, Boston, \\ Massachusetts 02115, Department of Pediatric Oncology, Dana-Farber Cancer Institute and \\ Children's Hospital Boston, Harvard Medical School, Boston, Massachusetts 02115, and Howard \\ Hughes Medical Institute, Harvard Medical School, Boston, Massachusetts 02115
}

Transcription factor p53 induces cell cycle arrest and apoptosis in response to DNA damage ${ }^{1}$ and cellular stress, ${ }^{2}$ thereby playing a critical role in protecting cells from malignant transformation. The E3 ubiquitin ligase hDM2 controls p53 levels through a direct binding interaction that neutralizes p53 transactivation activity, exports nuclear p53, and targets it for degradation via the ubiquitylation-proteasomal pathway. ${ }^{3,4}$ Loss of p53 activity, either by deletion, mutation, or hDM2 overexpression, is the most common defect in human cancer. ${ }^{5}$ Tumors with preserved expression of wild type p53 are rendered vulnerable by pharmacologic approaches that stabilize native p53. In this context, hDM2 targeting has emerged as a validated approach to restore p53 activity and resensitize cancer cells to apoptosis in vitro and in vivo. ${ }^{6}$

The $\mathrm{p} 53-\mathrm{hDM} 2$ protein interaction is mediated by the 15-residue a-helical transactivation domain of p53, which inserts into a hydrophobic cleft on the surface of hDM2. ${ }^{7}$ Three residues within this domain (F19, W23, and L26) are essential for hDM2-binding. ${ }^{8,9} \mathrm{We}$ sought to optimize the $\mathrm{p} 53$ peptide as a biological tool and prototype therapeutic by enforcing its a-helical structure while preserving the key interacting residues that enable specific hDM2 engagement. We previously developed a "peptide stapling" strategy in which an all-hydrocarbon cross-link is generated within natural peptides by ruthenium-catalyzed olefin metathesis of inserted a, a-disubstituted nonproteogenic amino acids bearing olefinic side chains (Figure 1A). ${ }^{10}$ We report the application of this strategy to the generation of stabilized alpha-helix of p53 (SAH-p53) peptides that exhibit high affinity for hDM2, and, in contrast to the corresponding unmodified p53 peptide, readily enter cells through an active uptake mechanism. SAH-p53 treatment reactivated the p53 tumor suppressor cascade by inducing the transcription of p53-responsive genes, providing the first example of a stapled peptide that kills cancer cells by targeting a transcriptional pathway.

To design SAH-p53 compounds, we placed synthetic olefinic derivatives at positions that avoid critical hDM2-binding residues. Hydrocarbon staples spanning the $i, i+7$ positions

Supporting Information Available: Complete ref 16h, peptide characterization, experimentals, and supplementary figures. This material is available free of charge via the Internet at http://pubs.acs.org. 
were generated by olefin metathesis (Figure 1A). An initial panel of four SAH-p53 peptides was synthesized, each containing a distinctively localized cross-link (Figure 1B). To evaluate the structural impact of installing an all-hydrocarbon $i, i+7$ staple, we conducted circular dichroism (CD) experiments to determine a-helicity. While the wild type p53 peptide displayed 11\% a-helical content in water at pH 7.0, SAH-p53s 1-4 demonstrated 10-59\% a-helicity (Figure 1B,C). Fluorescence polarization binding assays using hDM2 ${ }_{17-125}$ and FITC-labeled derivatives of SAH-p53s 1-4 identified $\mathbf{4}$ as a subnanomolar interactor, having an affinity for hDM2 almost 3 orders of magnitude greater than that of the wild type peptide (Figure 1B,D). SAH-p53-4 also demonstrated improved proteolytic stability (Supporting Information, Figure 1).

We found that the initial SAH-p53 compounds generated were incapable of penetrating intact Jurkat T-cells (Figure 1B, Supporting Information, Figure 2). We noted that SAH-p53s 1-4 were negatively charged (-2) at physiological $\mathrm{pH}$. Positive charge is a characteristic feature of certain classes of cell penetrating peptides. ${ }^{11}$ In developing a second generation of compounds, we replaced aspartic and glutamic acids with asparagines and glutamines to adjust peptide charge and mutated select amino acids previously reported to participate in p53 nuclear export (L14Q) and ubiquitylation (K24R) ${ }^{4,12}$ (Figure 1B). SAH-p53s 5-8 exhibited a 2-fold to 8.5-fold enhancement in a-helical content, retained high binding affinity for hDM2, and demonstrated time- and temperature-dependent cellular uptake by FACS and confocal microscopy (Figure 1B,E,F, Supporting Information, Figure 3). Cell viability assays using RKO or SJSA-1 cancer cells exposed to SAH-p53 peptides indicated that SAH-p53-8, which contained point mutations in both nuclear export and ubiquitylation sites, was the only structurally stabilized, cell-permeable, and high affinity hDM2 binder that adversely affected cell viability (Figures $1 \mathrm{~B}$ and $4 \mathrm{~A}$ ).

To determine if hDM2-targeting by SAH-p53-8 could specifically restore native p53 levels, we treated SJSA-1 cells with wild-type, 8 , and $\mathbf{8}_{\mathbf{F} 19 \mathrm{~A}}$ peptides for $8-30 \mathrm{~h}$ and monitored $\mathrm{p} 53$ protein levels by Western analysis (Figure 2). Cells exposed to SAH-p53-8 demonstrated increased p53 proteins levels that peaked at $18 \mathrm{~h}$ post-treatment. The $\mathrm{p} 53$ resuppression by $24 \mathrm{~h}$ correlated with the time-dependent upregulation of hDM2 by p53, consistent with an intact p53-hDM2 counter-regulatory mechanism. ${ }^{13}$ SAH-p53-8 likewise induced upregulation of the cyclin-dependent kinase inhibitor p21. ${ }^{14}$ The p21 upregulation in cells treated with 8 was detected at $12 \mathrm{~h}$, reaching peak levels at $18 \mathrm{~h}$. Baseline levels were restored by $30 \mathrm{~h}$, consistent with resuppression of native p53. The hDM2 and p21 levels were unchanged in SJSA-1 cells treated with wild-type or $\mathbf{8}_{\mathbf{F} 19 \mathrm{~A}}$, highlighting the specificity of SAH-p53-8 modulation of the p53 signaling pathway.

To examine whether SAH-p53-8-mediated stabilization of native p53 could inhibit cancer cells by reactivating the apoptotic pathway, we conducted viability and caspase-3 assays using SJSA-1 cells exposed to wild-type, $\mathbf{8}$, and $\mathbf{8}_{\mathbf{F 1 9 A}}$ for $24 \mathrm{~h}$ (Figure 3). Whereas the wild-type and $\mathbf{8}_{\mathbf{F 1 9 A}}$ peptides had no effect on cell viability, SAH-p53-8 exhibited dosedependent inhibition of SJSA-1 cell viability $\left(\mathrm{EC}_{50}=8.8 \mu \mathrm{M}\right)$. Analysis of caspase-3 activation by fluorescence monitoring of the cleaved caspase- 3 substrate Ac-DEVD-AMC ${ }^{15}$ showed that neither the wild-type nor the $\mathbf{8}_{\mathbf{F} 19 \mathrm{~A}}$ peptides had any apoptotic effect; however, 8 triggered dose-dependent caspase- 3 activation $\left(\mathrm{EC}_{50}=5.8 \mu \mathrm{M}\right)$ that was blocked by 
DEVD-CHO, a specific caspase-3 inhibitor, demonstrating that SAH-p53-8 specifically inhibited cell viability by activating apoptosis in hDM2-over-expressing SJSA-1 cells.

The identification of multiple organic compounds and $\mathrm{p} 53$ peptidomimetics with anti-hDM2 activity ${ }^{8,16}$ holds promise for achieving clinical benefit from manipulating the p53 pathway. By generating a stapled peptide-based hDM2 inhibitor, we have documented an in situ interaction between SAH-p53-8 and hDM2 (Supporting Information, Figure 4), confirming that its pro-apoptotic activity derives from restoration of the $\mathrm{p} 53$ pathway. The successful pharmacologic optimization of the transactivating a-helix of p53 suggests that this methodology may enable the development of a wide array of peptidic compounds to probe protein interactions and target deregulated transcriptional pathways for therapeutic benefit in cancer.

\section{Supplementary Material}

Refer to Web version on PubMed Central for supplementary material.

\section{Acknowledgment.}

This manuscript is dedicated to K. C. Nicolaou on the occasion of his 60th birthday and to Stanley J. Korsmeyer. We thank D. Brown, M. Salanga, and T. Diefenbach for confocal support and Eric Smith for editorial assistance. F.B. is the recipient of a Ruth L. Kirchstein NRSA F32CA103510. L.D.W. is supported by NHLBI Grant K08HL074049, a Burroughs-Wellcome Career Award, and a Culpeper Scholarship. This work was also supported by the Harvard/Dana-Farber Program in Cancer Chemical Biology.

\section{References}

(1). Kastan MB; Onyekwere O; Sidransky D; Vogelstein B; Craig RW Cancer Res. 1991, 51, 63046311. [PubMed: 1933891]

(2). Wu X; Bayle JH; Olson D; Levine AJ Genes Dev. 1993, 7, 1126-1132. [PubMed: 8319905] Yonish-Rouach E; Resnftzky D; Lotem J; Sachs L; Kimchi A; Oren M Nature 1991, 352, 345347. [PubMed: 1852210] Momand J; Zambetti GP; Olson DC; George D; Levine AJ Cell 1992, 69, 1237. [PubMed: 1535557]

(3). Levine AJ; Hu W; Feng Z Cell Death Differ. 2006, 13, 1027. [PubMed: 16557269] Honda R; Tanaka H; Yasuda H FEBS Lett. 1997, 420, 25. [PubMed: 9450543] Tao W; Levine AJ Proc. Nat. Acad. Sci. U.S.A 1999, 96, 3077-3080.

(4). Li M; Brooks CL; Wu-Baer F; Chen D; Baer R; Gu W Science 2003, 302, 1972-1975. [PubMed: 14671306]

(5). Hollstein M; Sidransky D; Vogelstein B; Harris CC Science 1991, 253, 49-53. [PubMed: 1905840]

(6). Chène P Nat. Rev. Cancer 2003, 3, 102-109. [PubMed: 12563309]

(7). Kussie PH; Gorina S; Marechal V; Elenbaas B; Moreau J; Levine AJ; Pavletich NP Science 1996, 274, 948-953. [PubMed: 8875929]

(8). Sakurai K; Chung HS; Kahne DJ Am. Chem. Soc 2004, 126, 16288-16289.Vassilev LT; Vu BT; Graves B; Carvajal D; Podlaski F; Filipovic Z; Kong N; Kammlott U; Lukacs C; Klein C; Fotouhi N; Liu EA Science 2004, 303, 844-848. [PubMed: 14704432]

(9). Lin J; Chen J; Elenbaas B; Levine AJ Genes Dev. 1994, 8, 1235-1246. [PubMed: 7926727]

(10). Schafmeister CE; Po J; Verdine GL J. Am. Chem. Soc 2000, 122, 5891-5892.Walensky LD; Kung AL; Escher I; Malia TJ; Barbuto S; Wright RD; Wagner G; Verdine GL; Korsmeyer SJ Science 2004, 305, 1466-1470. [PubMed: 15353804]

(11). Vivès E; Lebleu B The Tat-Derived Cell-Penetrating Peptide In Cell-Penetrating Peptides: Processes and Applications; Langel Ü, Ed.; CRC Press: Boca Raton, 2002; pp 3-21. 
(12). Zhang Y; Xiong Y Science 2001, 292, 1910-1915. [PubMed: 11397945]

(13). Barak Y; Juven T; Haffner R; Oren M EMBO J. 1993, 12, 461-468. [PubMed: 8440237] Juven T; Barak Y; Zauberman A; George DL; Oren M Oncogene 1993, 8, 3411-3416. [PubMed: 8247544]

(14). Dulic V; Kaufmann WK; Wilson SJ; Tisty TD; Lees E; Harper JW; Elledge SJ; Reed SI Cell 1994, 76, 1013. [PubMed: 8137420] El-Deiry WS; Tokino T; Velculescu VE; Levy DB; Parsons R; Trent JM; Lin D; Mercer WE; Kinzler KW; Vogelstein B Cell 1993, 75, 817. [PubMed: 8242752]

(15). Pochampally R; Fodera B; Chen L; Lu W; Chen JJ Biol. Chem 1999, 274, 15271-15277.

(16). (a)Duncan SJ; Gruschow S; Williams DH; McNicholas C; Purewal R; Hajek M; Gerlitz M; Martin S; Wrigley SK; Moore MJ Am. Chem. Soc 2001, 123, 554-560.(b)Chène P; Fuchs J; Bohn J; Garcia-Echeverria C; Furet P; Fabbro DJ Mol. Biol 2000, 299, 245.(c)Sakurai K; Schubert C; Kahne DJ Am. Chem. Soc 2006, 128, 11000-11001.(d)Kritzer JA; Hodsdon ME; Schepartz AJ Am. Chem. Soc 2005, 127, 4118-4119.(e)Kritzer JA; Lear JD; Hodsdon ME; Schepartz AJ Am. Chem. Soc 2004, 126, 9468-9469.(f)Wasylyk C; Salvi R; Argentini M; Dureuil C; Delumeau I; Abecassis J; Debussche L; Wasylyk B Oncogene 1999, 18, 1921-1934. [PubMed: 10208414] (g)Garcia-Echeverria C; Chene P; Blommers MJJ; Furet PJ Med. Chem 2000, 43, 3205-3208.(h)Grasberger BL; et al. J. Med. Chem 2005, 48, 909-912. [PubMed: 15715460] 

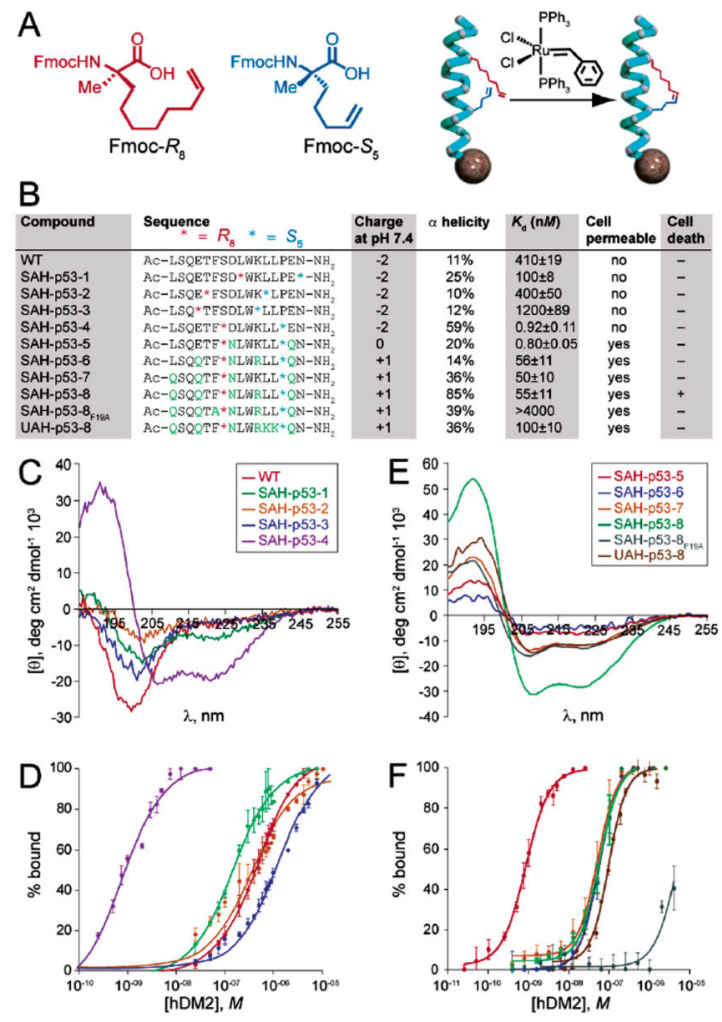

Figure 1.

Synthesis, sequence, and biochemical analysis of SAH-p53 peptides. (A) Non-natural amino acids were synthesized as described and cross-linked by ruthenium-catalyzed ring-closing olefin metathesis. (B) SAH-p53 compounds were generated by stapling the p53 $14-29$ sequence at the indicated positions. Charge, a-helicity, hDM2 binding affinity, cell permeability, and impact on cell viability are indicated for each compound. $(\mathrm{C}, \mathrm{E})$ Circular dichroism spectra revealed enhancement of a-helicity for SAH-p53 compounds. (D, F) Fluorescence polarization assays using FITC-peptides and hDM2 ${ }_{17-125}$ demonstrated subnanomolar hDM2-binding affinities for select SAH-p53 peptides. Note: UAH-p53-8 is the "unstapled" form of SAH-p53-8. 


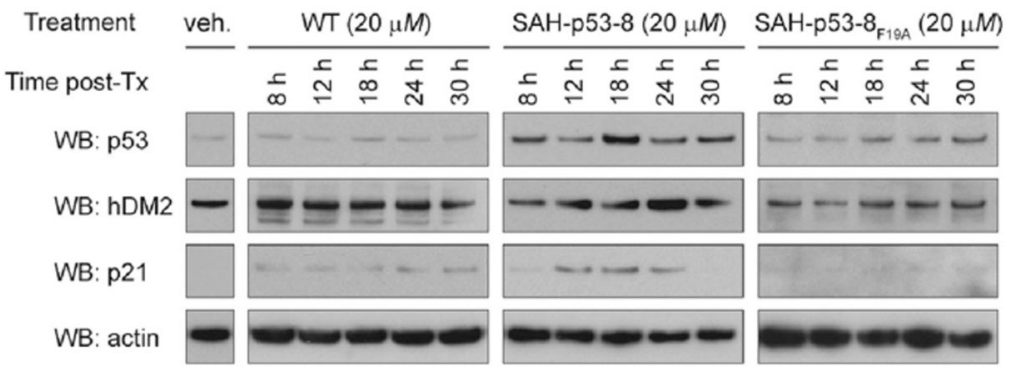

Figure 2.

SAH-p53-8 reactivates the p53 transcriptional pathway. The hDM2 overexpressing SJSA-1 cells were exposed to the indicated peptides, and Western analyses for p53, hDM2, and p21 were performed at $8-30 \mathrm{~h}$ of treatment. 

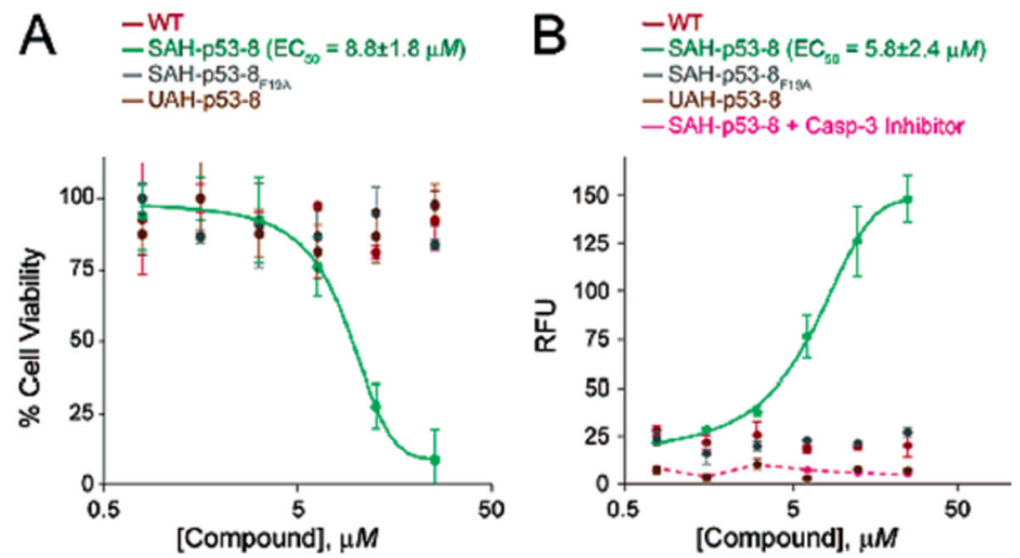

Figure 3.

Reactivation of apoptosis in SAH-p53-8-treated SJSA-1 cells. SAH-p53-8 demonstrated specific, dose-dependent cytotoxicity and apoptosis induction as measured by (A) CellTiterGlo (Promega) and (B) Caspase-3 activation assays (Oncogene). 